\title{
CDC HIV High Risk Donor Indicator
}

National Cancer Institute

\section{Source}

National Cancer Institute. CDC HIV High Risk Donor Indicator. NCI Thesaurus. Code C139271.

An indication as to whether an org an donor may fall into one or more behavioral categories associated with increased risk of human immunodeficiency virus (HIV) infection, as defined by the 1994 Centers for Disease Control (CDC) Public Health Service Criteria for High Risk Behavior (Guidelines for preventing transmission of human immunodeficiency virus through transplantation of human tissue and organs. Centers for Disease Control and Prevention. MMWR Recomm Rep 1994; 43: 1-17). 